\title{
Low Affinity Immunoglobulin Gamma Fc Region Receptor III-B
}

National Cancer Institute

\section{Source}

National Cancer Institute. Low Affinity Immunoglobulin Gamma Fc Region Receptor III-B. NCI Thesaurus. Code C38561.

Low affinity immunog lobulin gamma Fc region receptor III-B (233 aa, 26 kDa) is encoded by the human FCGR3B gene. This protein plays a role in binding to monomeric or aggregated immunog lobulins. 